\title{
Public Policies of Welfare State and Child Poverty in the European Union
}

\author{
Angeles Sánchez ${ }^{1, *(\mathbb{D})}$ and María Navarro ${ }^{2}$ \\ 1 Department of Applied Economics, University of Granada, 18071 Granada, Spain \\ 2 Department of Economics and Business, University of Almeria, 15690 Almeria, Spain; marianh@ual.es \\ * Correspondence: sancheza@ugr.es
}

check for

updates

Citation: Sánchez, A.; Navarro, M. Public Policies of Welfare State and Child Poverty in the European Union. Sustainability 2021, 13, 2725. https:// doi.org/10.3390/su13052725

Academic Editor: Gideon Baffoe

Received: 15 February 2021

Accepted: 24 February 2021

Published: 3 March 2021

Publisher's Note: MDPI stays neutral with regard to jurisdictional claims in published maps and institutional affiliations.

Copyright: (c) 2021 by the authors. Licensee MDPI, Basel, Switzerland. This article is an open access article distributed under the terms and conditions of the Creative Commons Attribution (CC BY) license (https:/ / creativecommons.org/licenses/by/ $4.0 /)$.

\begin{abstract}
Combating child poverty is desirable to ensure equality of opportunities across children, as well as fostering the sustainability of the societal well-being for future generations. This paper focuses on the study of child poverty in the 28 Member States of the European Union over the period 2008-2018. We analyse the relationship between child poverty and government social expenditure by controlling it with tax structure (ratio direct taxes over indirect taxes), economic growth and socio-demographic characteristics. For that, we rely on panel data methodology. This paper has verified that the effectiveness of the government social spending programmes to reduce child poverty also depends on the progressiveness of the country's tax structure. Government spending on health and education programmes could be more effective in reducing child poverty in Member States with less progressive tax structure, provided they reached the average level of public spending for the whole of the European Union. By contrast, a positive relationship between child poverty and government social protection spending regardless of the tax structure of countries was found. In this case, the underlying forces that lead to less effectiveness of social protection programmes are also stronger in the less progressive Member States.
\end{abstract}

Keywords: public policy; child poverty; government social spending; tax structure; welfare state; education; health; social protection; economic growth; panel data estimation

\section{Introduction}

The main aim of this paper is to analyse the relationship between child poverty and government social expenditure in the 28 Member States of the European Union (EU) throughout the period 2008-2018. Following the classification of The United Nations (Appendix A), in this paper, government social expenditure includes spending on health, education and social protection. That is to say, this article not only considers social protection programmes whose goals are to prevent or reduce poverty, but also spending on education and health programmes, since as preferred goods, they can contribute to correcting negative externalities, and promoting equal opportunities throughout the life cycle [1].

During the last few decades, child poverty and social exclusion have become a relevant issue for the majority of the governments in developed countries. In the context of the EU, the most recent pro-poorness and social inclusion policies are framed in the Europe 2020 Strategy (2010-2020). The Europe 2020 Strategy opted for the "Beyond Gross Domestic Product (GDP)" initiative, explicitly recognising the multidimensional character of poverty [2]. In this vein, in order to assess the achievement in the target of reducing the EU poverty by 20 million people, a new multidimensional poverty indicator was developed: people at risk of poverty or social exclusion (AROPE). In addition to monetary poverty, AROPE considers an indicator of low work intensity and another of severe material deprivation to capture aspects regarding social exclusion. This indicator is also calculated for the population under 16 years of age and provides an approximation of multidimensional 
child poverty. Looking to the future, Sustainable Development Goals (SDGs), adopted by the 194 United Nations Member States (including EU countries) in 2015, provides a longer term horizon and an impetus to consider Europe's goals up to 2030 [3]. The first goal in the Target 1.2 of SDGs focuses on reducing "at least by half the proportion of men, women and children of all ages living in poverty in all its dimensions according to national definitions" [4] (p. 19). It is likely to be the first time that a global development initiative has explicitly highlighted the fight against multidimensional child poverty as one of its targets. To achieve this goal, it should be necessary to invest in children, directly or through fathers, under the scope of an inclusive growth strategy that allows improvement of living standards and shared prosperity across all social groups [5].

The analysis and prevention of the widespread and persistent phenomenon of child poverty is of particular interest mainly by two different reasons. Firstly, children are the most vulnerable group in terms of increased poverty in the EU, especially during the last economic crisis. Figure 1 reports the evolution of poverty, measured by AROPE, from 2008 to 2018 for the whole of the EU-28 in different targets of population. Figure 1 shows that poverty levels are always higher for children than for the rest (total, working-age and elder population), especially during the economic crisis. Moreover, we can observe that there is a decrease of poverty levels after the economic crisis for the different targets of population, except for the elder population, whose poverty have been increasing since 2015. In any case, children continue to be the most affected group by poverty.

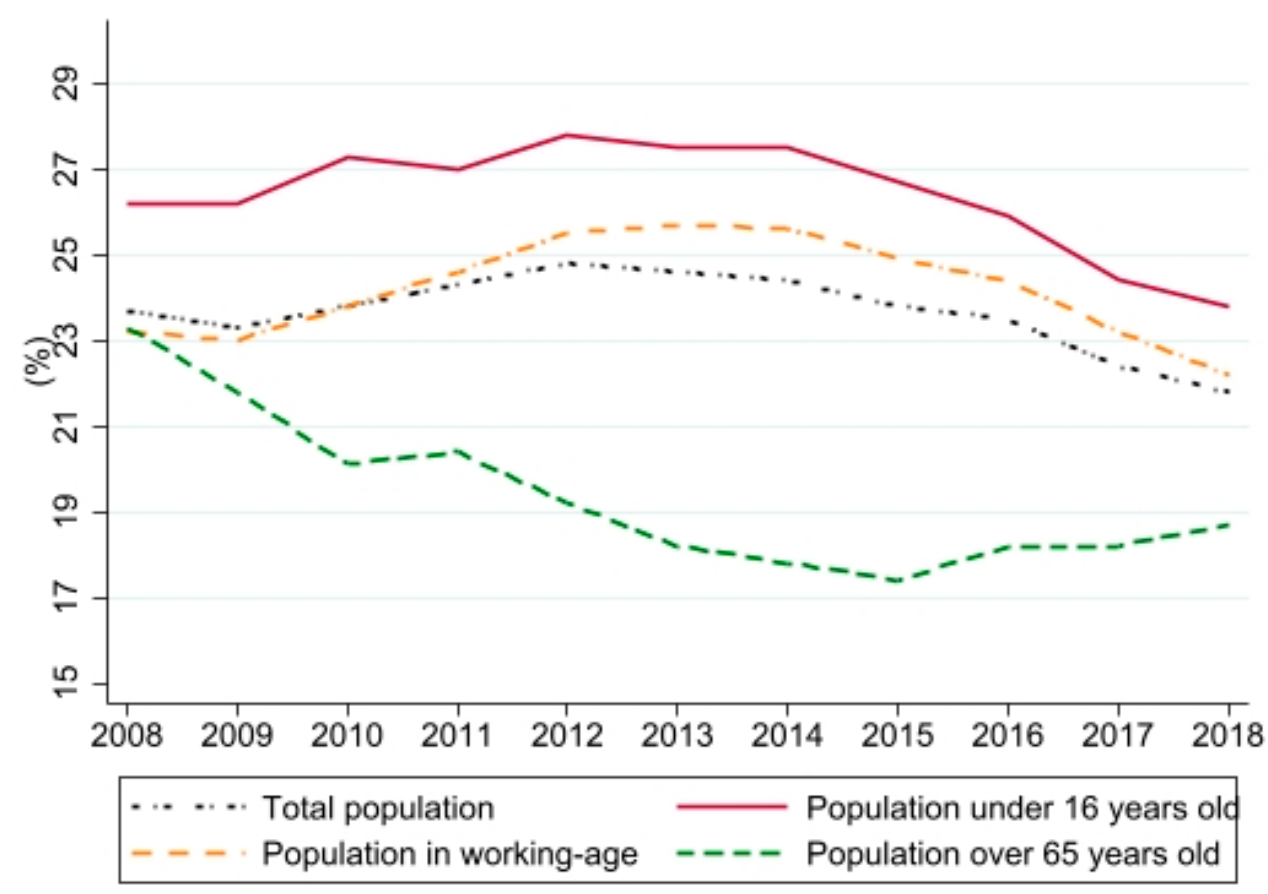

Figure 1. Evolution of poverty in the European Union (EU)-28 for the total population, children, working-age population and population over 65 years old (2008-2018). For the years 2008 and 2009, information for the EU-27 rather than EU-28 is included. Adapted from Eurostat, Income and Living Conditions.

Secondly, as literature on the welfare state highlights, the social and economic future of a country depends on its capacity to fight child poverty and social exclusion, since these problems represent a threat to future generations in terms of both economic development and social stability [6,7]. That is to say, child poverty represents a threat for the sustainability of the societal well-being for future generations. This could be explained through the vicious circle established between child poverty and income inequality, as explained below. Growing up in poverty can have a lasting impact on a child. Poor children are more likely to become poor adults because they will suffer more illnesses, live in a more tumultuous 
environment, suffer material deprivation of goods and services that are necessary for their physical, mental, emotional and intellectual development, and drop out of school early [8-11]. Consequently, in the future, when they become adults, they will opt for lower qualification jobs and also lower wages. This sequence of circumstances can lead to increases in social and economic inequalities [12]. The circle is complete since the transmission of poverty from parents to children is powerfully determined by the degree of income inequality. In unequal societies, the socio-economic background of family exerts a stronger influence on children's future education and life chance [1]. Thus, social mobility is lower in countries with higher income differences [13]. Therefore, combating child poverty is desirable to ensure equality of opportunities across children, as well as fostering improvements of living standards and prosperity for society as a whole over time, in order to achieve a sustainable development [5,14-16]. Additionally, the reduction of child poverty — as a mechanism that perpetuates the maintenance of income inequalitiescould foster environmental sustainability. Given that the widening of income inequalities in developed countries is intensifying the status of consumerism (more polluting), that causes the most damage to the planet, as well as the fact that the fight against climate change requires coordinated action for the common good, moving towards more egalitarian societies would be a necessary step to reach progress on environmental sustainability [17].

Taking into account that the first years of life are fundamental to preventing the recreation on the cycle of inter-generational poverty of children until adults, from a societal welfare point of view, it is relevant to design social policy measures in order to reduce child poverty [18]. The literature on the welfare state reveals a large range of results regarding the contribution of social spending policies to this goal. A key aspect pointed out by the welfare state literature is that during the 2000s, the orientation of the European welfare state programmes has changed. The new approach has been focused on investment in human capital rather than on passive cash transfers. The idea of the EU social investment agenda was to get people out of poverty by moving them into the labour world [19]. Keeping this new approach in mind, empirical studies showed that Member States with higher levels of investment in social spending register lower child poverty rates [18,20,21]. Nevertheless, the relationship between child poverty and the different categories of social spending is not clearly established. Considering the items of government spending in education and health, related literature has found that a higher spending in both helps to reduce child poverty rates $[12,20,22]$. However, the association between spending on social protection and child poverty is not well defined. Due to the change in the orientation of social programmes mentioned above, the social protection programmes registered a shift in their orientation so that new programmes associated with the transition to a postindustrial society have prevailed. The new programmes are focused on reconciling work and family, single parenthood, or people possessing low or obsolete skills. Several studies conclude that these new programmes are less redistributive because most of them are not targeted towards the poor $[23,24]$. Likewise, since eligibility conditions for social protection programmes have become stricter, the redistributive effects of these programmes have declined $[25,26]$. In short, the effectiveness of social protection programmes on reducing poverty depends on how they are designed, their implementation and the institutional context of the country $[5,20,27,28]$.

In this paper, we analyse the relationship between government social expenditure or welfare state programmes and child poverty in the 28 Member States of the EU, over the period 2008-2018. Within the social expenditure, we consider specifically the government spending in education, health and social protection. Likewise, and taking into account that child poverty and the effectiveness of social spending policies may differ not only at country level but also depending on the social protections systems and the characteristics of welfare states [22,29], we distinguish between two groups of Member States. The first group is made up of the Member States that throughout the 2008-2018 period had a tax system (ratio of direct taxes over indirect taxes) that is more progressive than that of the EU-28 as a whole, and the rest of the Member States would make up the second group. 
Keeping this in mind, this paper aims to check three hypotheses. The first hypothesis is that public policies of welfare state can act as buffers for child poverty, so that the government social expenditure as a whole should contribute to alleviating child poverty. The second hypothesis is that, taking into account the literature, probably not all the categories of social expenditure have the same effectiveness. Finally, the third hypothesis is that the correlation between social spending and child poverty in the EU may be different in each of the two groups of countries studied. To test these hypotheses, we rely on panel data methodology. We use the information from several datasets of Eurostat.

Our main findings show that child poverty and government social spending are negatively correlated. Arguably, government social spending is an effective tool for reducing child poverty since, after economic crisis, a higher social spending contributed to reduce child poverty in the Member States. The same findings are reached for the spending on education and health. However, the relationship between child poverty and government social protection spending is positive. Likewise, results confirm our hypothesis that the correlation between child poverty and government social spending differs depending on the tax structure of the Member States.

The rest of this paper is structured as follows. Section 2 presents the dataset and variables used in the analysis and justifies their choice. Section 3 describes the empirical strategy to study the relationship between child poverty and government social spending. Section 4 reports the main results of the study. Lastly, in Section 5, main conclusions are drawn and discussed.

\section{Data and Variables}

In this paper, we used highly balanced macro-panel data from Eurostat on child risk-ofpoverty, government social spending, tax structure and economic and socio-demographic variables of EU-28 Member States, over the period 2008-2018. Appendix B contains the description of variables analysed and the Eurostat database from which the information comes.

\subsection{Child Poverty and Explanatory Variables}

The dependent variable in our analysis is Child Poverty. It is measured by the AROPE indicator for children under 16 years old, which expresses the percentage of the population younger than 16 at risk of poverty or social exclusion. For its construction, the counting or head-counting methodology is followed. More specifically, its value represents the percentage of the population younger than 16 that in one or more of the three dimensions registers values below the established thresholds, namely: $60 \%$ of the country's median equivalised disposable income, inability to enjoy four or more items on a list of nine consumption goods and services and households where its members worked less than $20 \%$ of their potential during the previous 12 months. These three concepts are called, respectively, rate of poverty risk, severe material deprivation and low work intensity.

The adoption of the AROPE index represented a qualitative advance as official recognition in European Community institutions that poverty is not just a lack of income, so that for monitoring progress towards the EU social protection and social inclusion, relative deprivation must be taken into account [30]. In this vein, AROPE is not only defined by the consideration of people with low income, it is extended to interactions with social exclusion and considers child living conditions in the household, being a multidimensional poverty measure. This new approach allows going beyond traditional measures of monetary poverty to understand and monitor poverty dynamics among children [31].

The explanatory variables in our analysis can be classified into three different groups: fiscal policy, economic growth and socio-demographic factors. In the first group related to fiscal policy, we consider the variable Government Social Spending, which accounts for the sum of government spending in education, health and social protection (see Appendix A), the three variables for the specific type of spending (Government Education Spending, 
Government Health Spending and Government Social Protection Spending), as well as a variable to account for the tax structure of the Member State (Tax Structure).

A remarkable aspect of our work is that, unlike most studies that measure public spending as a percentage of GDP, we have expressed these measures in constant 2015 Euros per billion inhabitants. That way, we can make reliable time and cross-sectional comparisons and avoid the problem of underestimating the public spending effort of some Member States like Ireland, which has very high GDP.

The distributive incidence of public spending as well as its relationship with child poverty must be analysed in conjunction with the tax structure, or relationship between direct and indirect taxes, in order to account for how the expenditures are financed [12,32]. Progressive taxation and a better design of social programmes may contribute to a higher degree of efficiency targeted towards the poorest [21]. To consider the effects of the progressivity of taxation of the country, first, we have estimated the ratio of direct taxes over indirect taxes for each country. Next, we calculated the mean of this ratio for each country over the 11 years studied. Finally, we built the dummy variable Tax Structure which takes the value 1 if the ratio of the country is greater than the mean for the EU-28 (0.99) and 0 otherwise. In this way, the countries with Tax Structure equal to 1 present a greater relative weight of direct taxes-over the indirect- than the whole of the EU-28 in the period of time analysed. That is to say, they show a more progressive tax structure under the EU context. These countries are Belgium, Denmark, Finland, Germany, Ireland, Italy, Luxembourg, Malta, Netherlands and United Kingdom.

The growth rate of GDP is introduced in the models to take into account the influence of economic context on child poverty. Previous studies have evidenced that economic growth has played a very relevant role in the progress of combating poverty [33,34]. This variable is called Economic Growth Rate and is introduced in the models with a delay of two years since, as shown in Figure A1 of Appendix C, during the period of time analysed, a symmetric relationship is observed between the percentage variation of Child Poverty and the growth rate of GDP, but with that time lag.

In the last group, we control for socio-demographic factors related to education and characteristics of the household. Particularly, to consider one of the most relevant channels of child poverty, that is, education [20], we include the variable Early Leavers which reflects the percentage of population aged 18 to 24 who has dropped out of education and training. A positive relationship between Early Leavers and Child Poverty is expected. Regarding the characteristics of the household, literature states that both the age of the mothers at birth of the first child and the composition of the family correlate with child poverty. It has been found that a higher proportion of adolescent women in the country at birth of first child affects their opportunities for higher education and increases the risk of leaving the school system. Arguably, the average age of women at birth of her first child is a factor that may increase the risk of living in poverty, for both women and their children [20]. As regards the composition of the household, the most extended result in related literature has been that children living in single-parent households register higher poverty rate than others living in two-parent families $[1,3,7,20]$. An explanation could be that single-parent families could provide less emotional and cognitive motivation to children, which can also affect future performance in school and other domains of life [35]. We define the variables Age Childbirth and Single Parent Family which measures the mean age of women at birth of first child and the distribution of population in single households with dependent children, respectively.

\subsection{A First Approach to Data}

An explorative analysis of the data will help us to hypothesize about the type of underlying relationships between Child Poverty and the explanatory variables of our database. Table 1 shows the descriptive statistics of the studied variables differentiating the information in both directions, between and within. 
Table 1. Descriptive statistics of child poverty in 28 Members States, 2008-2018.

\begin{tabular}{ccccccc}
\hline Variable & & Mean & SD & Min & Max & Observations \\
\hline Child Poverty & overall & 26.21 & 8.82 & 12.60 & 52.80 & $\mathrm{~N}=306$ \\
& between & & 8.37 & 14.57 & 47.81 & $\mathrm{n}=28$ \\
& within & & 3.08 & 12.94 & 36.84 & $\mathrm{~T}=10.93$ \\
G. Social Spending & overall & 8.05 & 5.77 & 1.03 & 26.16 & $\mathrm{~N}=308$ \\
& between & & 5.85 & 1.28 & 25.20 & $\mathrm{n}=28$ \\
& within & & 0.43 & 5.75 & 9.58 & $\mathrm{~T}=11$ \\
G. Education Spending & overall & \multirow{2}{*}{1.43} & 0.99 & 0.19 & 5.02 & $\mathrm{~N}=308$ \\
& between & & 1.00 & 0.22 & 4.53 & $\mathrm{n}=28$ \\
G. Health Spending & within & & 0.11 & 0.94 & 1.92 & $\mathrm{~T}=11$ \\
& overall & \multirow{2}{*}{1.77} & 1.20 & 0.21 & 4.54 & $\mathrm{~N}=308$ \\
& between & & 1.21 & 0.29 & 4.32 & $\mathrm{n}=28$ \\
G. Social Protection & within & & 0.13 & 1.25 & 2.26 & $\mathrm{~T}=11$ \\
Spending & overall & 4.85 & 3.66 & 0.58 & 17.22 & $\mathrm{~N}=308$ \\
& between & & 3.71 & 0.76 & 16.35 & $\mathrm{n}=28$ \\
Growth Economic Rate & within & & 0.28 & 3.42 & 5.75 & $\mathrm{~T}=11$ \\
& overall & \multirow{2}{*}{1.39} & 3.72 & -14.8 & 25.20 & $\mathrm{~N}=308$ \\
& between & & 1.41 & -2.48 & 4.78 & $\mathrm{n}=28$ \\
Early Leavers & within & & 3.45 & -15.15 & 22.26 & $\mathrm{~T}=11$ \\
& overall & \multirow{2}{*}{10.84} & 5.52 & 2.80 & 34.90 & $\mathrm{~N}=308$ \\
& between & & 5.08 & 4.02 & 23.86 & $\mathrm{n}=28$ \\
Age Childbirth & within & & 2.33 & 2.09 & 25.19 & $\mathrm{~T}=11$ \\
& overall & \multirow{2}{*}{30.07} & 1.17 & 26.50 & 32.20 & $\mathrm{~N}=308$ \\
& between & & 1.12 & 27.19 & 31.72 & $\mathrm{n}=28$ \\
& within & & 0.40 & 28.98 & 31.00 & $\mathrm{~T}=11$ \\
& overall & 4.32 & 1.81 & 1.10 & 9.80 & $\mathrm{~N}=306$ \\
& between & & 1.80 & 1.45 & 7.83 & $\mathrm{n}=28$ \\
& within & & 0.43 & 2.89 & 6.29 & $\mathrm{~T}=10.93$
\end{tabular}

Note. $\mathrm{G}$ = Government; $\mathrm{N}$ = number of observations; $\mathrm{n}$ = number of countries; $\mathrm{T}$ = number of average years per country; $\mathrm{SD}=$ standard deviation. Adapted from Eurostat: Income and Living Conditions, Government and Finance Statistics, Annual National Accounts, Labour Force Survey and Fertility.

Figure 2 displays the relationship between child poverty and government social spending for the 28 Member States over 2008-2018, distinguishing between Member States with a more progressive tax structure (Tax Structure $=1$, blue dots in Figure 2) and the rest (Tax Structure $=0$, orange dots in Figure 2).

As a first glance, it is observed that greater social spending and greater progressivity in tax structures go hand in hand. Nevertheless, there are two exceptions: Sweden (orange dots located in the central part of the Figure 2), which has a less progressive structure than the EU-28 as a whole and its average level of public social spending is the third highest in the EU (14.89 on average in 2008-2018), and Malta (blue dots located on the left of the Figure 2), which makes an average expenditure of 4.67, despite presenting a more progressive structure. In addition, more government social spending, progressivity in tax structure and lower levels of child poverty are linked in all countries, except in two with a small population size (Czech Republic and Slovenia, orange dots located in the lower left corner) that present low rates of child poverty in the period analysed (about 17\%), low level of social spending and a less progressive tax structure. Focusing on the differentiation of the two groups of countries based on the progressivity of their tax structures, a different performance is observed. In the group of countries with a more progressive tax structure (blue dots in Figure 2), the negative relationship between government social spending and child poverty is more clearly observed than in the other group. In order to analyse theses intuitions more deeply, we contrast whether there are statistically significant differences in the variables of interest between both groups of countries (Table 2). 


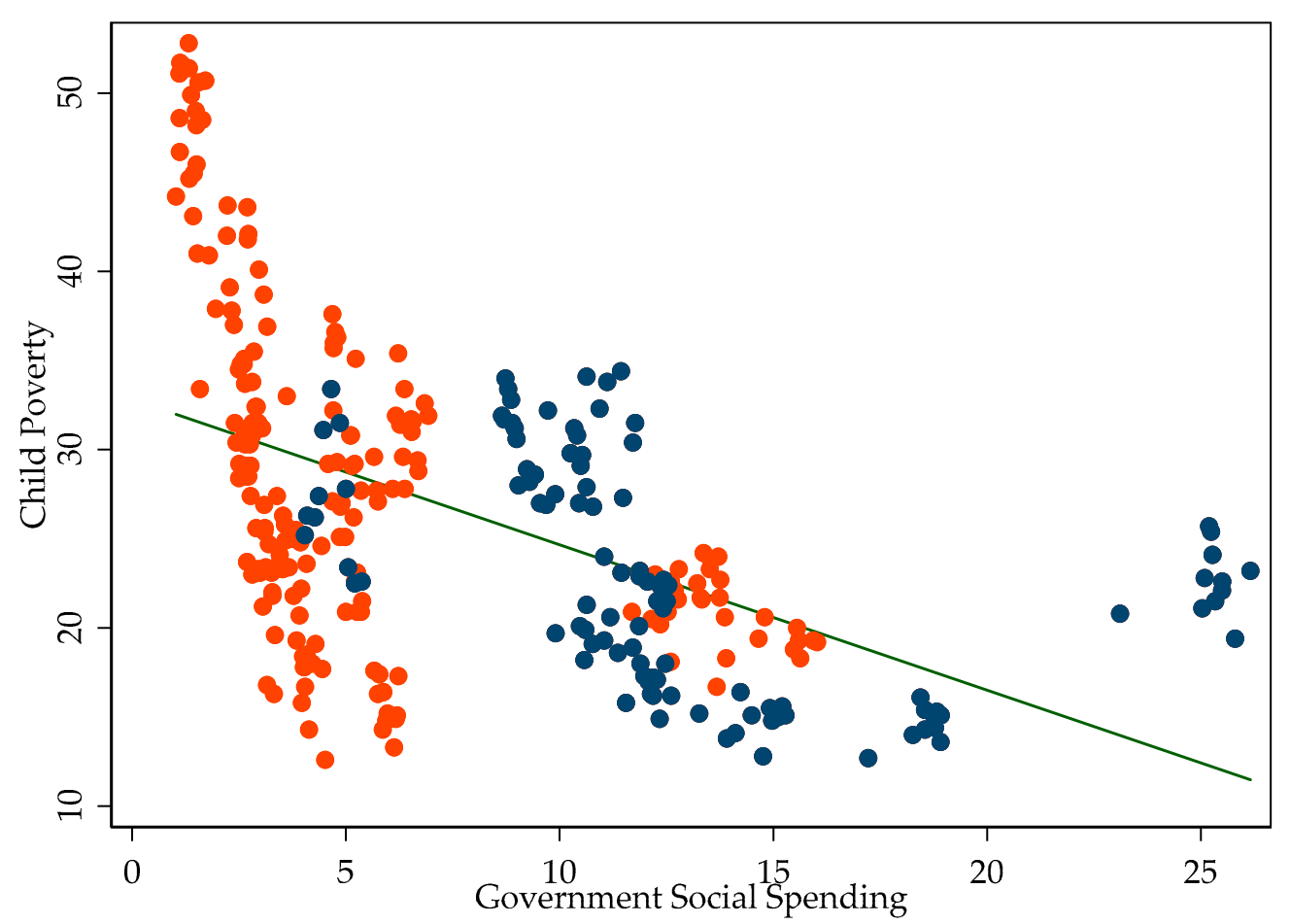

Figure 2. Child poverty and government social spending in the EU-28, 2008-2018. In blue, countries with tax structure above the average of the EU-28: Belgium, Denmark, Finland, Germany, Ireland, Italy, Luxembourg, Malta, Netherlands and United Kingdom. In orange, countries with tax structure below the average of EU-28: Bulgaria, Czechia, Estonia, Greece, Spain, France, Croatia, Cyprus, Latvia, Lithuania, Hungary, Austria, Poland, Portugal, Romania, Slovenia, Slovakia and Sweden. Child Poverty is measured in percentage of the population under 16, and Government Social Spending in constant 2015 Euros per billion inhabitants. Adapted from Eurostat, Income and Living Conditions and Government and Finance Statistics.

Table 2. Differences in mean between the Member States of the EU-28, depending on the progressiveness of the tax structure, 2008-2018.

\begin{tabular}{cccccc}
\hline & EU-28 & More Progressive $^{\mathbf{a}}$ & Less Progressive $^{\mathbf{b}}$ & $\boldsymbol{t}$-Test \\
\hline Variables & $\boldsymbol{n = 1 1}$ & $\boldsymbol{n = 1 1 0}$ & $\boldsymbol{n = 1 9 8}$ & $\boldsymbol{t}(\boldsymbol{p}$-Value) & Cohen's d \\
\hline Child Poverty & 26.43 & 22.65 & 28.20 & $5.54(<0.001)$ & 0.90 \\
G. Social Spending & 8.78 & 12.85 & 5.38 & $-13.88(<0.001)$ & 1.65 \\
G. Education Spending & 1.40 & 2.23 & 0.98 & $-13.20(<0.001)$ & 1.57 \\
G. Health Spending & 2.02 & 2.85 & 1.16 & $-16.04(<0.001)$ & 1.91 \\
G. Social Protection & 5.37 & 7.77 & 3.23 & $-12.96(<0.001)$ & 1.54 \\
$\quad$ Spending & & & & & \\
\hline
\end{tabular}

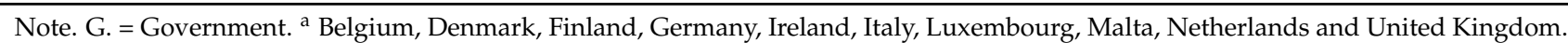

b Bulgaria, Czechia, Estonia, Greece, Spain, France, Croatia, Cyprus, Latvia, Lithuania, Hungary, Austria, Poland, Portugal, Romania, Slovenia, Slovakia and Sweden. Child Poverty is measured in percentage of the population under 16, and Government Social Spending in constant 2015 Euros per billion inhabitants. Adapted from Eurostat, Income and Living Conditions and Government and Finance Statistics.

The results in Table 2 show that in the group of the 10 Member States with a more progressive tax structure, in average terms, child poverty is lower, and the level of expenditure is bigger in all the kinds of spending, in contrast with the remaining 18 Member States. Likewise, we check the existence of statistically significant differences, which are big in all cases (Cohen's d > 0.8).

These findings lead us to raise the possibility that the variability in child poverty could also be explained by differences in progressivity in the tax structure. In order to contrast this possibility, we include in our regression models the interaction between Tax Structure 
and the variables of government social spending. The idea is to contrast whether the relationship between government social spending and child poverty could be conditioned by the fact that a country has a more or less progressive tax structure than the EU-28 as a whole. To sum up, we study whether the correlation between government social spending and child poverty is different in the more progressive Member States in terms of tax structure compared to the rest of the Member States.

\section{Empirical Strategy}

Equation (1) shows the specification of the model, which allows us to analyse the relationship between government social spending and child poverty:

$$
P_{i t}=\omega_{0}+\beta^{\prime} G_{i t}+\lambda^{\prime} T_{i}+\rho^{\prime} G_{i t} \times T_{i}+\eta^{\prime} X_{i t}+\alpha_{i}+u_{i t}
$$

$i$ denotes the country and the year. $P_{i t}$ is the level of child poverty in the country $i$ in the year $t, G_{i t}$ represents the variables of government social expenditure, $T_{i}$ is the variable dummy, to have a more progressive tax structure than the EU-28 as a whole, $G_{i t} \times T_{i}$ is the interaction term that reflects the effect of having a more progressive tax structure on child poverty of government social expenditure, $X$ is a set of socio-economic variables in which the two-years lagged GDP growth is included, $\alpha_{i}$ is the individual effect of each of the countries or unobservable heterogeneity invariant in time and $u_{i t}$ is the error term.

The next stage is to analyse which method of estimating the model is the most appropriate depending on the nature of the data. To achieve that, various tests must be carried out [36-38]. The first step is to check whether the individual effects $\left(\alpha_{i}\right)$ are necessary in the model specification. If there are individual effects in our sample, then a panel data methodology should be used. In turn, the individual effects can be treated as random or fixed. The individual effects are random when they are not correlated with the explanatory variables, and they are fixed when they are correlated with the explanatory variables. Specifically, the results of the Breusch and Pagan Lagrangian Multiplier (Chi2 (01) = 520.01, $p<0.001)$ that compares random effects with pooled, as well as those of the restrictive $\mathrm{F}$ test $(\mathrm{F}(26,206)=35.75, p<0.001)$, comparing fixed effects with pooled, indicate that individual country effects should be taken into account. In other words, there are significant differences between the countries analysed (panel effects) that affect child poverty in the EU and, therefore, the model cannot be estimated correctly without taking into account the space and time dimensions. The next step is to decide what treatment should be given to individual effects, such as random or fixed. The Hausman test (Chi2 $(10)=33.16$, $p=0.0003$ ) reveals that the fixed and random effect estimators differ substantially, so our models must be specified as fixed effects. All the tests have been carried out taking as baseline a specification with all the government expenditures and control variables, but not including the interactions.

In order to achieve an efficient estimation of the coefficients and an unbiased estimation of standard errors, it would be necessary to test whether the error term verifies the Gauss Markov assumptions [39]. Specifically, the presence of heteroskedasticity (the individual error terms $\alpha_{i}$ do not have the same variance), autocorrelation or serial correlation (the errors within each country are temporally correlated) and contemporary correlation (the errors of different countries are correlated) are checked. The results of the modified Wald test for group-wise heteroskedasticity in a fixed effect regression model reveals the presence of heteroskedasticity (Chi2 $=699.98, p<0.001)$. Autocorrelation has also been detected with the Wooldridge test for panel data $(\mathrm{F}(1,26)=34.476, p<0.001)$. Finally, contemporary correlation is not detected (Pesaran's test of cross-sectional independence $=$ $1.756, p=0.0790$ and Friedman's test of cross-sectional independence $=11.852, p=0.9920$ ).

Detected problems can be solved with various estimation methods. The most widely used in the literature are Feasible Generalized Least Squares (FGLS) and Panel Corrected Standard Errors (PCSE), both with a heteroskedastic but uncorrelated error structure and an AR1 autocorrelation structure [40,41]. In a very influential work [42], it was argued that PCSE is the best alternative because the estimated standard errors have better statistical 
properties and are more precise than those calculated by FGLS. Furthermore, the authors pointed out that when the number of units $(\mathrm{N})$ is greater than the number of years $\mathrm{T}$ (which is not our case), the FGLS method should not be used. However, later works [41,43] concluded that PCSE is not always the best alternative. Depending on the $\mathrm{T} / \mathrm{N}$ ratio ( $\mathrm{T}$ is the number of years and $\mathrm{N}$ is the number of countries), heteroskedasticity levels, and the degree of serial correlation, both PCSE and FGLS can provide efficient estimates of coefficients and poor estimates of confidence intervals and, vice versa, make efficient estimates of confidence intervals and not so good estimations of the coefficients.

Following the proposal of previous literature, we estimate the fixed effects model collected in Equation (1) with the two estimators: FGLS and PCSE. Since we have also verified the existence of time fixed effects in our data $(\mathrm{F}(8,209)=2.88, p=0.0046))$, we include a set of year dummies which account for yearly changes that are the same for all countries in order to contrast the existence of an effect common to all countries changing over time.

\section{Results}

Table 3 shows the results of the models estimated with the estimators FGLS and PCSE. As a baseline, we present Models 1 and 2 without the interaction between variables of spending and Tax Structure (direct taxes over indirect taxes), both estimated using FGLS. The results of the estimations with PCSE are quite similar, but for the sake of the brevity of the table, we do not include them. Models 3, 4, 5 and 6 consider the interaction with Tax Structure in order to take into account the distinction between Member States with a more progressive tax structure than the EU-28 as a whole, and the rest of the Member States with a less progressive tax structure. Models 3 and 4 have been estimated with the estimator FGLS and Models 5 and 6 with PCSE. Firstly (Models 1, 3 and 5), we study the relationship between child poverty and government social spending as a whole, and next (Models 2, 4 and 6), we study the relationship between child poverty and the different items of social spending. In the six models, all the control variables have been included.

Table 3. Regression analysis: child poverty and government social spending in the EU-28, 2008-2018.

\begin{tabular}{|c|c|c|c|c|c|c|}
\hline $\begin{array}{c}\text { Dependent Variable Child } \\
\text { Poverty }\end{array}$ & Model 1 & Model 2 & Model 3 & Model 4 & Model 5 & Model 6 \\
\hline Government Social Spending & $\begin{array}{l}-0.561 * * * \\
(0.144)\end{array}$ & & $\begin{array}{l}-0.741^{* * *} \\
(0.204)\end{array}$ & & $\begin{array}{l}-0.919 * * * \\
(0.222)\end{array}$ & \\
\hline $\begin{array}{l}\text { G. Social Spending X Tax } \\
\text { Structure }\end{array}$ & & & $\begin{array}{l}0.498 \text { * } \\
(0.283)\end{array}$ & & $\begin{array}{c}0.754^{* * *} \\
(0.292\end{array}$ & \\
\hline $\begin{array}{l}\text { Government Education } \\
\text { Spending }\end{array}$ & & $\begin{array}{c}-2.749 * \\
(1.539)\end{array}$ & & $\begin{array}{c}-5.962 * * \\
(2.364)\end{array}$ & & $\begin{array}{c}-7.562^{* * *} \\
(2.444)\end{array}$ \\
\hline $\begin{array}{l}\text { G. Education Spending X Tax } \\
\text { Structure }\end{array}$ & & & & $\begin{array}{c}5.063 \\
(3.107)\end{array}$ & & $\begin{array}{l}5.442^{*} \\
(3.296)\end{array}$ \\
\hline Government Health Spending & & $\begin{array}{c}-3.440 \text { ** } \\
(1.496)\end{array}$ & & $\begin{array}{c}-6.179 * * \\
(2.787\end{array}$ & & $\begin{array}{c}-7.841^{* * *} \\
(2.804)\end{array}$ \\
\hline $\begin{array}{l}\text { G. Health Spending X Tax } \\
\text { Structure }\end{array}$ & & & & $\begin{array}{c}3.545 \\
(3.440)\end{array}$ & & $\begin{array}{l}7.407^{* *} \\
(3.577)\end{array}$ \\
\hline $\begin{array}{l}\text { Government Social Protection } \\
\text { Spending }\end{array}$ & & $\begin{array}{l}0.909 * \\
(0.535)\end{array}$ & & $\begin{array}{l}2.462 \text { ** } \\
(1.052)\end{array}$ & & $\begin{array}{c}3.296^{* * *} \\
(1.093)\end{array}$ \\
\hline $\begin{array}{l}\text { G. Social Protection Spending X } \\
\text { Tax Structure }\end{array}$ & & & & $\begin{array}{c}-1.961 \text { * } \\
(1.185)\end{array}$ & & $\begin{array}{c}-2.862 * * \\
(1.244)\end{array}$ \\
\hline
\end{tabular}


Table 3. Cont.

\begin{tabular}{|c|c|c|c|c|c|c|}
\hline $\begin{array}{c}\text { Dependent Variable Child } \\
\text { Poverty }\end{array}$ & Model 1 & Model 2 & Model 3 & Model 4 & Model 5 & Model 6 \\
\hline Tax Structure & $\begin{array}{l}-0.945 \\
(1.275)\end{array}$ & $\begin{array}{c}0.394 \\
(1.637)\end{array}$ & $\begin{array}{l}-2.409 \\
(1.696)\end{array}$ & $\begin{array}{l}-0.673 \\
(1.697)\end{array}$ & $\begin{array}{l}-1.081 \\
(1.751)\end{array}$ & $\begin{array}{l}-0.774 \\
(1.712)\end{array}$ \\
\hline Growth Economic Rate (t-2) & $\begin{array}{c}-0.169^{* * *} \\
(0.517)\end{array}$ & $\begin{array}{c}-0.166^{* * *} \\
(0.048)\end{array}$ & $\begin{array}{c}-0.157^{* * *} \\
(0.047)\end{array}$ & $\begin{array}{c}-0.170 * * * \\
(0.051)\end{array}$ & $\begin{array}{c}-0.148^{* * *} \\
(0.053)\end{array}$ & $\begin{array}{c}-0.144^{* *} \\
(0.056)\end{array}$ \\
\hline Early Leavers & $\begin{array}{c}0.332 * * * \\
(0.096)\end{array}$ & $\begin{array}{c}0.273^{* * *} \\
(0.098)\end{array}$ & $\begin{array}{c}0.313^{* * * *} \\
(0.102)\end{array}$ & $\begin{array}{c}0.347^{* * *} \\
(0.097)\end{array}$ & $\begin{array}{c}0.335^{* * *} \\
(0.109)\end{array}$ & $\begin{array}{c}0.412^{* * *} \\
(0.102)\end{array}$ \\
\hline Age Childbirth & $\begin{array}{c}-1.285 * \\
(0.721)\end{array}$ & $\begin{array}{l}-1.165 \\
(0.785)\end{array}$ & $\begin{array}{c}-0.998 \\
(0.806)\end{array}$ & $\begin{array}{c}-1.173 \\
(0.751)\end{array}$ & $\begin{array}{c}-1.697 * \\
(0.881)\end{array}$ & $\begin{array}{c}-1.994^{* *} \\
(0.794)\end{array}$ \\
\hline Single Parent Family & $\begin{array}{l}0.495 * \\
(0.277)\end{array}$ & $\begin{array}{l}0.590 * * \\
(0.287)\end{array}$ & $\begin{array}{l}0.674^{* *} \\
(0.287)\end{array}$ & $\begin{array}{l}0.620^{* *} \\
(0.303)\end{array}$ & $\begin{array}{c}0.532 \\
(0.328)\end{array}$ & $\begin{array}{l}0.619^{*} \\
(0.337)\end{array}$ \\
\hline Observations (countries) & $252(28)$ & $252(28)$ & $252(28)$ & $252(28)$ & $252(28)$ & $252(28)$ \\
\hline Test of Wald (Chi2) & $90.11^{* * *}$ & $90.08^{* * *}$ & $80.60^{* * *}$ & $105.28^{* * *}$ & $94.96^{* * *}$ & $124.60 * * *$ \\
\hline R-squared & & & & & 0.708 & 0.737 \\
\hline Rho & & & & & 0.877 & 0.836 \\
\hline
\end{tabular}

Note. G. = Government. Estimators used: Feasible Generalized Least Squares (Models 1-4) and Panel Corrected Standard Errors (Models 5 and 6). The government social spending variables are centred with respect to their means. Standard errors in parentheses. A constant term and time dummies are included in all the models. ${ }^{*} p<0.1,{ }^{* *} p<0.05,{ }^{* * *} p<0.01$.

At a first glance, without interactions, a negative association is observed between child poverty and government social spending as a whole (Model 1). Thus, hypothesis 1 is confirmed, which means that government social spending can buffer child poverty. Considering the different concepts of social spending, higher spending on education and health would help to reduce child poverty, while there is a positive relationship between spending on social protection and child poverty (Model 2). In this way, hypothesis 2 is also confirmed. The results of Models 3, 4, 5 and 6, in which we have considered the possibility that the correlation between government social spending and child poverty may be different in each of the two groups of countries studied (hypothesis 3), could shed more light on the interpretation of the results.

When interactions between variables are considered, it is necessary to analyse the joint significance of their corresponding parameters in order to deduce whether the interaction is statistically significant [38]. Table 4 displays the association between child poverty and government social spending (and its items), ceteris paribus, in the more progressive Member States and the remaining. For Member States with a more progressive tax structure, the marginal effect of a variable is equal to the estimated coefficient of the variable plus the estimated coefficient of the interaction variable with the dummy variable Tax Structure. The column "Wald test" of Table 4 shows the results of the Wald test of joint significance of the parameters of social spending variables and the parameters of interaction variables. All of them are statistically significant.

The marginal impact analysis indicates that the results go in the same direction, namely, negative relationship between education and health spending and child poverty, and positive association between social protection and child poverty are found in both groups on countries. Likewise, our hypothesis is confirmed, and the capacity of reducing child poverty with public spending policies is different in both groups of countries. In countries with a more progressive tax structure, it could be argued that increases in spending (especially in education and health) would have less impact on reducing child poverty. However, it should be stressed that, among other reasons, due to its greater progressivity in taxes and greater budgetary effort in public spending, this group of countries registers lower child poverty rates (22.65\% over 2008-2018, Table 2 ) than the whole of the EU-28 $(26.43 \%)$ and that reached by the less progressive Member States (28.20\%). 
Table 4. Marginal impact of government social spending in child poverty, EU-28 (2008-2018).

\begin{tabular}{|c|c|c|c|c|c|c|}
\hline \multirow[b]{2}{*}{ Variables } & \multicolumn{2}{|c|}{ FGLS } & \multirow{2}{*}{$\begin{array}{c}\text { Wald Test } \\
\text { Chi2(2) ( } p \text {-Value) }\end{array}$} & \multicolumn{2}{|c|}{ PCSE } & \multirow{2}{*}{$\begin{array}{c}\text { Wald Test } \\
\text { Chi2(2) }(p \text {-Value })\end{array}$} \\
\hline & Progressive $^{a}$ & Rest $^{b}$ & & Progressive $^{a}$ & Rest $^{b}$ & \\
\hline $\begin{array}{l}\text { G. Social } \\
\text { Spending }\end{array}$ & -0.24 & -0.74 & $13.81(0.0010)$ & -0.17 & -0.92 & $17.30(0.0002)$ \\
\hline $\begin{array}{l}\text { G. Education } \\
\text { Spending }\end{array}$ & -0.90 & -5.96 & $6.60(0.0370)$ & -2.12 & -7.56 & $10.64(0.0049)$ \\
\hline $\begin{array}{l}\text { G. Health } \\
\text { Spending } \\
\text { G. Social }\end{array}$ & -2.63 & -6.18 & $7.26(0.0265)$ & -0.43 & -7.84 & $7.98(0.0185)$ \\
\hline $\begin{array}{l}\text { Protection } \\
\text { Spending }\end{array}$ & 0.50 & 2.46 & $6.05(0.0485)$ & 0.44 & 3.30 & $9.42(0.0090)$ \\
\hline
\end{tabular}

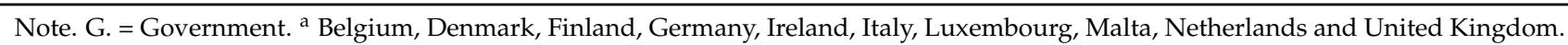

b Bulgaria, Czechia, Estonia, Greece, Spain, France, Croatia, Cyprus, Latvia, Lithuania, Hungary, Austria, Poland, Portugal, Romania,

Slovenia, Slovakia and Sweden. FGLS = Feasible Generalized Least Squares. PCSE = Panel Corrected Standard Errors.

On the other hand, the capacity of reducing child poverty by increasing the government spending in education and health is greater in the Member States with a less progressive tax structure. In order to interpret these results more deeply, we will focus on the government health spending, whose impact on child poverty is big in both types of Member States. Within the group of less progressive tax structure countries, for each euro per billion inhabitants that a country managed to raise its average spending on health above the value of EU-28 (2.02 Euros per billion inhabitants, see Table 2), a reduction on a range of 6.18-7.84 percentage points in child poverty (depending on the estimator FGLS or PCSE) would be expected. However, taking into account that the average spending in health in this group is very low (1.16 euro per billion inhabitants), a large budgetary effort in these countries would be necessary to reduce child poverty at the predicted level. The conclusions for education spending are quite similar. Although, in countries with less progressivity in their tax structure, expansionary fiscal policies in education and health would be very effective in reducing child poverty, they have a long path before reaching the levels of child poverty of the more progressive Member States. They first should meet the average levels of the EU-28 as a whole of government social spending.

As regards the government social protection spending, a positive correlation with child poverty has been found in all the estimated models. Marginal impact analysis shows that the underlying forces that make social protection spending less effective in reducing child poverty are stronger in countries with less fiscal progressiveness than in the rest (2.46-3.30 in the less progressive group compared to 0.44-0.55 in the other group, see Table 4).

Lastly, in the case of control variables, in all the models, we find a negative relationship between child poverty and economic growth. The three remaining variables-of our models-account for the social aspects that may affect child poverty. Dropping out of school and living in a single parent family are positively correlated to child poverty, while the higher the age of the mother at birth of the first child, the lower the incidence of child poverty.

\section{Discussion and Conclusions}

Social and economic future of a society depends on its capacity to fight child poverty and social exclusion, since these problems represent a threat to sustainability of the European Welfare State for future generations. In the context of the EU-28, the people at risk of poverty or social exclusion under 16 years old represented, in 2018, 23.8\% of this population. But what is more worrying is that children are the group most affected by multidimensional poverty. The study of determinants of child poverty across countries and with a time perspective is of a big interest for policy decisions and for designing more specific and successful policies to solve this problem. 
This paper focuses on the study of the relationship between child poverty and public policies of welfare state in the EU-28 over the period 2008-2018. More specifically, we set up three aims, to check (1) whether the government social expenditure contributes to alleviating child poverty, (2) whether all the categories of social expenditure have the same effect and (3) to contrast the possibility that the correlation between social spending and child poverty may be different depending on the tax structure of the Member States. To address these issues, we estimated several models relying on panel methodology. More specifically, we have applied two different estimators (FGLS and PCSE) which led us to similar results, thus showing the robustness of the results.

Our results indicate that government social spending considered as a whole has the expected effect on child poverty. In line with most papers [18,20,21], a negative relationship has been found. Thus, in the context of economic crisis, especially until 2014, when Member States put into practice the contractive measures to foster the stability of public finances (approved in The Euro Plus Pact, in December 2011 [44]), reductions in social expenditure and increases in child poverty could be associated. In the subsequent period of economic recovery, increases in public social spending have contributed to reducing child poverty. However, the relationship between child poverty and the different categories of social expenditures is not similar. In all the estimated models, and in accordance with previous studies $[12,20,22]$, we find a negative relationship between child poverty and government spending on education and health, whereas a positive correlation is found with government social protection spending. Likewise, our findings lead us to confirm our hypothesis that the correlation between child poverty and government social spending differs depending on the tax structure of the Member States.

This means that studying public expenditures in conjunction with the tax structureor the relationship between direct and indirect taxes-of the Member States provides a better perspective of analysis [12,32]. According to our results, government spending on education and health could have a greater capacity to reduce child poverty in the Member States with less progressive tax structure. Nevertheless, it is worth stressing that given the gap in government expenditure between these countries and those which have a more progressive tributary system, a huge budgetary effort would be required. For instance, in health, they would first have to increase their spending until they managed to increase their average level from 1.16 Euros per billion of inhabitants to 2.02, which is the average for the EU-28. From there, for each unit that they managed to increase their average spending in health, larger reductions in the country's average child poverty would be predictable than in countries with more progressive tax structure.

As regards the government social protection spending, the question is: Why does it not contribute to reduce the child poverty? As has already been stated in a previous section, several changes in the orientation of the European welfare state programmes during the 2000s would lead to forecasting a loss of effectiveness of public spending on social benefits to reduce child poverty. Within this new framework, social protection programmes are preferentially focused on reconciling work and family, single parenthood, or people possessing low or obsolete skills, so that these programmes are less redistributive because most of them are not targeted to the poor [23,24]. Additionally, since eligibility conditions for social protection programmes have become stricter, the redistributive effects of these programmes have declined $[25,26]$. More specifically, and in line with our results, two studies developed in the same context of the European Union [12,45] conclude that a positive relationship between child poverty (or poverty in the second one) and social protection could arise depending on the kind of welfare state analysed. The first study stressed that in the Member States where old-aged pensions have a high weight in social spending, this programme may arguably have a structural crowding-out effect on spending and investments in alternative policies, such as investments in education and child-care, which might be more effective in addressing child poverty. The second study concludes that for countries other than the Nordic welfare states, there might be a positive relationship between expenditure shifts towards new welfare state programmes and stagnating or even increasing poverty trends. 
In our classification, the Nordic countries-except Sweden-are included in the group with more progressive tax structure where the estimated parameter for spending in social protection is positive but lower than in the group of the less progressive countries.

In addition, it is worth noting that during the economic crisis, several countries belonging to the group of Member States with less progressive tax structure (for instance Greece, Portugal and Spain) were severely hit and went through a protracted fiscal consolidation and slow recovery. Their fragmented social protection systems were not able to protect the incomes of households with children and they registered increases in child poverty rates [21].

Regarding the control variables, in all the models, we found a negative relationship between child poverty and economic growth. That is, consistent with previous studies [32,46], we can conclude that the economic crisis with low rates of GDP growth, even negative in several Members State, has contributed to the increase in child poverty in several Member States. The three remaining variables, which account for the social aspects that may affect child poverty, display similar ones to other papers. Dropping out of school and living in a single parent family are positively related to child poverty, while the higher the age of the mother at birth of the first child, the lower the incidence of child poverty $[3,7,20]$.

All in all, not only does the level of social spending matter, but also the way in which it is targeted more or less specifically at the poorest population. This paper adds to the debate on effectiveness of social spending as a buffer of child poverty, filling-in several gaps. Firstly, the role that an institutional characteristic, such as the tax system of the Member States, can play is analysed. We have verified that the effectiveness of the government spending programmes to reduce child poverty also depends on the progressiveness of the country's tax structure. Secondly, although usually this kind of study is focused on social protection programmes - whose goals are to prevent or reduce poverty-this paper analyses spending on education and health programs too, since as preferred goods, they can contribute to correcting negative externalities, and promoting equal opportunities throughout the life cycle [1]. Thirdly, from a methodological point of view, there are two remarkable aspects: the use of homogeneous databases for the period of time analysed (see Reference [47] to check the misleading results that may appear), and the use of a unit of measurement for government expenditure that accounting for the effect size of the countries and the time series, has provided reliable and comparable results. As future research directions, we would highlight a deeper study on the relationship between child poverty and social spending, focusing on the type of programme (i.e., primary school, secondary school, pensions, unemployment, family and children, minimum living income, etc.) and also considering the way to implement them (monetary transfers or kind services).

Author Contributions: Conceptualization, A.S. and M.N.; methodology, A.S.; software, A.S. and M.N.; validation, A.S. and M.N.; formal analysis, A.S. and M.N.; investigation, A.S. and M.N.; resources, A.S. and M.N.; data curation, M.N.; writing—original draft preparation, A.S. and M.N.; writing-review and editing, A.S. and M.N.; visualization, A.S. and M.N.; supervision, A.S. and M.N.; project administration, A.S. and M.N.; funding acquisition, A.S. and M.N. All authors have read and agreed to the published version of the manuscript.

Funding: This research was funded by the Programme SEJ-393 of the Regional Government of Andalucía (Spain).

Data Availability Statement: The data presented in this study are openly available in Eurostat https: / / ec.europa.eu/eurostat/web/main/data/database (accessed on 2 March 2021).

Conflicts of Interest: The authors declare no conflict of interest. The funders had no role in the design of the study; in the collection, analyses, or interpretation of data; in the writing of the manuscript, or in the decision to publish the results. 


\section{Appendix A}

Table A1. Concepts of government social expenditure.

\begin{tabular}{cc}
\hline Type of Government Social Spending & Concepts \\
\hline 07. Health & 07.1 Medical products, appliances and equipment \\
& 07.2 Outpatient services \\
09. Education & 07.4 Public health services \\
& 07.5 R\&D Health \\
& 07.6 Health n.e.c. \\
& 09.1 Pre-primary and primary education \\
09.2 Secondary education \\
09.3 Post-secondary non-tertiary education \\
09.4 Tertiary education \\
09.5 Education not definable by level \\
09.6 Subsidiary services to education \\
09.7 R\&D Education \\
09.8 Education n.e.c. \\
10.1 Sickness and disability \\
10.2 Old age \\
10.3 Survivors \\
10.4 Family and children \\
10.5 Unemployment \\
10.6 Housing \\
10.7 Social exclusion n.e.c. \\
10.8 R\&D Social protection \\
10.9 Social protection n.e.c.
\end{tabular}

Note. n.e.c: not elsewhere classified. Adapted from United Nations Statistic Division, International Economic and Social Classifications.

\section{Appendix B}

Table A2. Description and source of the variables.

\begin{tabular}{ccc}
\hline Variable & Description & Eurostat Database \\
\hline & $\begin{array}{c}\text { Child poverty is measured using the at-risk } \\
\text { of poverty indicator (AROPE). AROPE } \\
\text { reflects the share of the population under 16 } \\
\text { years old who meet at least one the following } \\
\text { three conditions: at risk of poverty and/or } \\
\text { severely materially deprived, and/or living } \\
\text { in a very low work intensity household. }\end{array}$ & $\begin{array}{c}\text { Income and Living } \\
\text { Conditions }\end{array}$ \\
& It is the sum of public expenditure on health, \\
& education and social protection of the & \\
General Government of each country & Government and \\
Government Social & (Central Government, State Government, & Finance Statistics \\
Spending & Local Government and Social Security & \\
& Funds) in constant 2015 Euros per billion & inhabitants. \\
\hline Government & Government expenditure on education of the & \\
& General Government of each country & Government and \\
& (Central Government, State Government, & Finance Statistics \\
& Local Government and Social Security & \\
\hline & Funds) in constant 2015 Euros per billion & inhabitants. \\
\hline
\end{tabular}


Table A2. Cont.

\begin{tabular}{|c|c|c|}
\hline Variable & Description & Eurostat Database \\
\hline $\begin{array}{l}\text { Government Health } \\
\text { Spending }\end{array}$ & $\begin{array}{l}\text { Government expenditure on health of the } \\
\text { General Government of each country } \\
\text { (Central Government, State Government, } \\
\text { Local Government and Social Security } \\
\text { Funds) in constant } 2015 \text { Euros per billion } \\
\text { inhabitants. }\end{array}$ & $\begin{array}{l}\text { Government and } \\
\text { Finance Statistics }\end{array}$ \\
\hline $\begin{array}{l}\text { Government Social } \\
\text { Protection Spending }\end{array}$ & $\begin{array}{c}\text { Government expenditure on social protection } \\
\text { of the General Government of each country } \\
\text { (Central Government, State Government, } \\
\text { Local Government and Social Security } \\
\text { Funds) in constant } 2015 \text { Euros per billion } \\
\text { inhabitants. }\end{array}$ & $\begin{array}{l}\text { Government and } \\
\text { Finance Statistics }\end{array}$ \\
\hline Tax Structure & $\begin{array}{l}\text { The tax structure is the total of direct taxes } \\
\text { (as a percentage of GDP) divided by the total } \\
\text { of indirect taxes (as a percentage } \\
\text { Government and Finance Statistics of GDP). }\end{array}$ & $\begin{array}{l}\text { Government and } \\
\text { Finance Statistics }\end{array}$ \\
\hline Growth Economic Rate & Annual real GDP growth rate. & $\begin{array}{l}\text { Annual National } \\
\text { Accounts }\end{array}$ \\
\hline Early Leavers & $\begin{array}{l}\text { This indicator measures the share of the } \\
\text { population aged } 18 \text { to } 24 \text { with, at most, lower } \\
\text { secondary education who were not involved } \\
\text { in any education or training during the four } \\
\text { weeks preceding the survey. }\end{array}$ & Labour Force Survey \\
\hline Age Childbirth & Mean age of women at birth of first child. & Fertility \\
\hline Single Parent Family & $\begin{array}{l}\text { Distribution of population in single person } \\
\text { household with dependent children. }\end{array}$ & $\begin{array}{l}\text { Income and Living } \\
\text { Conditions }\end{array}$ \\
\hline
\end{tabular}

\section{Appendix C}

Figure A1 illustrates the symmetric relationship between Child Poverty (in growth rate) and economic growth. Especially during the first years, a certain lag is observed between the changes in GDP and the subsequent change in Child Poverty.

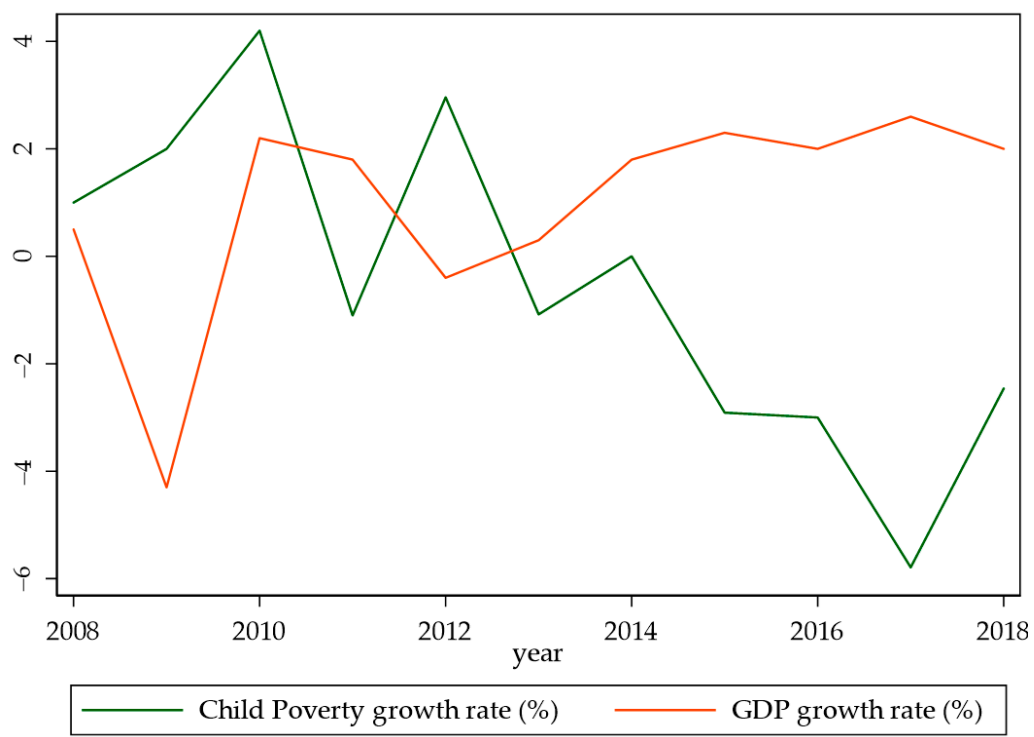

Figure A1. Relationship between child poverty and economic growth over 2008-2018 in the EU-28 as a whole. Adapted from Eurostat Income and Living Conditions and Annual National Accounts. 


\section{References}

1. Esping-Andersen, G. Families in the 21st Century; SNS Förlag: Stockholm, Sweden, 2016; ISBN 978-91-86949-81-5.

2. Sánchez, A.; Ruiz-Martos, M.J. Europe 2020 Strategy and Citizens' Life Satisfaction. J. Happiness Stud. 2018, 19, $2315-2338$. [CrossRef]

3. Atkinson, A.B.; Guio, A.-C.; Marlier, E. Monitoring Social Inclusion in Europe; Publications Office of the European Union: Luxembourg, 2017.

4. United Nations. World Population Prospects: The 2015 Revision; UN: New York, NY, USA, 2015.

5. OECD Can Social Protection Be an Engine for Inclusive Growth? Available online: https://doi.org/10.1787/9d95b5d0-en (accessed on 14 February 2021).

6. $\quad$ Esping-Andersen, G.; Gallie, D.; Hemerijck, A.; Myles, J. Why We Need a Neww Welfare State; Oxford University Press: New York, NY, USA, 2002.

7. Frazer, H.; Marlier, E. Progress across Europe in the Implementation of the 2013 EU Recommendation on Investing in Children: Breaking the Cycle of Disadvantage. In A Study of National Policies; European Social Policy Network; European Commission: Brussels, Belgium, 2017.

8. Evans, G.W. The Environment of Childhood Poverty. Am. Psychol. 2004, 59, 77. [CrossRef] [PubMed]

9. Figari, F.; Paulus, A.; Sutherland, H. Measuring the Size and Impact of Public Cash Support for Children in Cross-National Perspective. Soc. Sci. Comput. Rev. 2011, 29, 85-102. [CrossRef]

10. Field, F. The Foundation Years: Preventing Poor Children Becoming Poor Adults, The Report of the Independent Review on Poverty and Life Chances; The Stationery Office: London, UK, 2010.

11. Crawford, C.; Macmillan, L.; Vignoles, A. When and Why Do Initially High-Achieving Poor Children Fall Behind? Oxf. Rev. Educ. 2017, 43, 88-108. [CrossRef]

12. Diris, R.; Vandenbroucke, F.; Verbist, G. The Impact of Pensions, Transfers and Taxes on Child Poverty in Europe: The Role of Size, pro-Poorness and Child Orientation. Socio-Econ. Rev. 2017, 745-775. [CrossRef]

13. Corak, M. Income Inequality, Equality of Opportunity, and Intergenerational Mobility. J. Econ. Perspect. 2013, 27, 79-102. [CrossRef]

14. Liddle, B. Urbanization and Inequality/Poverty. Urban Sci. 2017, 1, 35. [CrossRef]

15. Chen, M.; Sui, Y.; Liu, W.; Liu, H.; Huang, Y. Urbanization Patterns and Poverty Reduction: A New Perspective to Explore the Countries along the Belt and Road. Habitat Int. 2019, 84, 1-14. [CrossRef]

16. Brazier, C.; UNICEF; Office of Research. Building the Future: Children and the Sustainable Development Goals in Rich Countries; UNICEF Office of Research-Innocenti: Florence, Italy, 2017; ISBN 978-88-6522-050-4.

17. Wilkinson, R.G.; Pickett, K. The Inner Level: How More Equal Societies Reduce Stress, Restore Sanity and Improve Everyone's Well-Being; Penguin Books: London, UK, 2020; ISBN 978-0-525-56124-8.

18. Aguayo, I.H.; Herráiz, E.D.; Marques, E.M.; Machado, I.; Almeida, S. Child at Risk of Poverty or Social Exclusion: Comparative View between Spain and Portugal in the European Context. Soc. Indic. Res. 2016, 129, 961-978. [CrossRef]

19. Vandenbroucke, F.; Vleminckx, K. Disappointing Poverty Trends: Is the Social Investment State to Blame? J. Eur. Soc. Policy 2011, 21, 450-471. [CrossRef]

20. Thévenon, O.; Manfredi, T.; Govind, Y.; Klauzner, I. Child Poverty in the OECD: Trends, Determinants and Policies to Tackle It; OECD: Paris, France, 2018.

21. Cantillon, B.; Chzhen, Y.; Handa, S.; Nolan, B. Children of Austerity: Impact of the Great Recession on Child Poverty in Rich Countries; Oxford University Press: Oxford, UK, 2017.

22. Benedetti, I.; Betti, G. Measuring Child Poverty and Its Uncertainty: A Case Study of 33 European Countries. Sustainability 2020, 12, 8204. [CrossRef]

23. Cantillon, B. The Paradox of the Social Investment State: Growth, Employment and Poverty in the Lisbon Era. J. Eur. Soc. Policy 2011, 21, 432-449. [CrossRef]

24. Wang, C.; Caminada, K.; Goudswaard, K. The Redistributive Effect of Social Transfer Programmes and Taxes: A Decomposition across Countries. Int. Soc. Secur. Rev. 2012, 65, 27-48. [CrossRef]

25. Wang, C.; Caminada, K.; Goudswaard, K. Income Redistribution in 20 Countries over Time. Int. J. Soc. Welf. 2014, 23, 262-275. [CrossRef]

26. Immervoll, H.; Richardson, L. Redistribution Policy and Inequality Reduction in OECD Countries: What Has Changed in Two Decades? OECD: Paris, France, 2011.

27. Lundvall, B.A.; Lorenz, E. Social Investment in the Globalising Learning Economy: A European Perspective. Soc. Investig. Welf. State 2012, 235-257.

28. Corak, M.; Lietz, C.; Sutherland, H. The Impact of Tax and Transfer Systems on Children in the European Union; UNICEF: Geneva, Switzerland, 2005.

29. OECD. An Overview of Growing Income Inequalities in OECD Countries: Main Findings; OECD: Paris, France, 2011.

30. Guio, A.-C.; Marlier, E. Amending the EU material deprivation indicator: Impact on size and composition of deprived population. In Monitoring Social Inclusion in Europe; Publications Office of the European Union: Luxembourg, 2017; p. 193.

31. Kim, H. Beyond Monetary Poverty Analysis: The Dynamics of Multidimensional Child Poverty in Developing Countries. Soc. Indic. Res. 2019, 141, 1107-1136. [CrossRef] 
32. Sánchez, Á.; Pérez-Corral, A.L. Government Social Expenditure and Income Inequalities in the European Union. Hacienda Pública Esp. 2018, 133-156.

33. Ravallion, M. The Economics of Poverty: History, Measurement, and Policy; Oxford University Press: Oxford, UK, 2015.

34. Brueckner, M.; Lederman, D. Inequality and Economic Growth: The Role of Initial Income; The World Bank: Washington, DC, USA, 2018.

35. Moon, S.H. Time to Invest in Disadvantaged Young Children1. SERI Q. 2012, 5, 51.

36. Baltagi, B.H. Econometric Analysis of Panel Data (Reprint, 5th Ed.); Wiley: London, UK, 2014.

37. Hsiao, C. Analysis of Panel Data; Cambridge University Press: Cambridge, UK, 2014.

38. Wooldridge, J.M. Econometric Analysis of Cross Section and Panel Data; MIT Press: Cambridge, MA, USA, 2010.

39. Kittel, B.; Winner, H. How Reliable Is Pooled Analysis in Political Economy? The Globalization-Welfare State Nexus Revisited. Eur. J. Polit. Res. 2005, 44, 269-293. [CrossRef]

40. Beck, N. Time-Series-Cross-Section Data: What Have We Learned in the Past Few Years? Annu. Rev. Polit. Sci. 2001, 4, 271-293. [CrossRef]

41. Reed, W.R.; Ye, H. Which Panel Data Estimator Should I Use? Appl. Econ. 2011, 43, 985-1000. [CrossRef]

42. Beck, N.; Kats, J. What to do (and not to do) with Time-Series Cross-Section Data. Am. Political Sci. Rev. 1995, 89, 634-647. [CrossRef]

43. Reed, W.R.; Webb, R. The PCSE Estimator Is Good-Just Not As Good As You Think. J. Time Ser. Econom. 2010, 2. [CrossRef]

44. European Council 24/25 March 2011. Annex I: The Euro Plus Pact. Stronger Economic Policy Coordination for Competitiveness and Convergence. Available online: https://www.consilium.europa.eu/uedocs/cms_data/docs/pressdata/en/ec/120296.pdf (accessed on 27 February 2021).

45. Vliet, O.V.; Wang, C. Social Investment and Poverty Reduction: A Comparative Analysis across Fifteen European Countries. J. Soc. Policy 2015, 44, 611-638. [CrossRef]

46. Muinelo-Gallo, L.; Roca-Sagalés, O. Joint Determinants of Fiscal Policy, Income Inequality and Economic Growth. Econ. Model. 2013, 30, 814-824. [CrossRef]

47. Galbraith, J.K. Causes of Changing Inequality in the World. Intereconomics 2016, 51, 55-60. [CrossRef] 